\title{
Chinese energy policy progress and challenges in the transition to low carbon development, 2006-2013
}

O progresso da política energética chinesa e os desafios na
transição para o desenvolvimento de baixo carbono, 2006-2013

http://dx.doi.org/10.1590/0034-7329201400211

LARISSA BASSO*

EDUARDO VIOLA**

Rev. Bras. Polit. Int. 57 (special edition): 174-192 [2014]

\section{Introduction}

If the world is not to jeopardize the conditions for human life on Earth, it must refrain from pursuing the current high carbon development. Science has proved that increased concentration of Greenhouse Gases (GHG) in the atmosphere is changing the climate equilibrium, a planetary boundary before a systemic disruption of Earth's delicate biophysical systems, and a key civilizational driver of the contemporary society. Following a low carbon development path will require substantial reduction of GHG emissions, therefore changes in the global energy matrix-still dominated by carbon intensive energy sources that account for more than half of the total emissions. This challenge will not be met if the largest GHG emitters and energy consumers do not commit to it.

China is the world's largest GHG emitter, energy producer and energy consumer. It also ranks first among the investors in low carbon energy technology. It has the largest installed capacity for wind energy, and exports solar photovoltaic panels for the whole world. Nevertheless, most of its energy is produced by fossil fuels, coal being its main power source. The accumulated social and environmental costs of exploiting coal are almost unbearable: air and water quality have deteriorated dramatically; Chinese rates of respiratory diseases are the highest in the world. There is hope, however: since 2006, China has questioned economic growth at all costs and is slowly tuning its policy framework to a more equitable and sustainable path.

* Institute of International Relations, University of Brasília, Brasília, DF, Brazil (larissabasso@gmail.com).

** Institute of International Relations, University of Brasília, Brasília, DF, Brazil (eduviola@gmail.com). 
It is the objective of this article to discuss the progress China has made from 2006 to 2013 and the challenges that remain for its transition to low carbon development. In order to do so, the article is organized in three parts. First, low carbon development is defined, followed by the Chinese energy-climate profile. After that, China's energy-climate policy developments are explored, and the Chinese profile in energy and climate governance is outlined. Finally, some important challenges for China's low carbon development are enumerated. The article defends that China has undergone important policy changes towards low carbon development, but must tackle key stumbling blocks before its full implementation.

\section{Low carbon development}

Sustainability is in the international agenda since the United Nations Conference on the Human Environment (1972), when it was decided that development should consider its impact on the environment. In 1987, the Brundtland Report or "Our Common Future" was released, and sustainable development was defined: "development that meets the needs of the present without compromising the ability of future generations to meet their own needs" (World Commission on Environment and Development 1987). The concept of sustainable development was adopted by the United Nations Conference on Environment and Development (1992) as the leading guideline for proposals and commitments.

Green economy was first used in a report for the UK government, ${ }^{1}$ and the concept is intended to frame the new economic model that should follow the global financial crisis. There is no official definition for green economy, but the most applied is "economy that results in improved human well-being and social equity, while significantly reducing environmental risks and ecological scarcities" (UNEP 2011 , 2). The concept was discussed during the United Nations Conference on Sustainable Development (2012), but there was no agreement to make it more prescriptive-the final report of Rio+20 states that green economy is "one of the important tools available for achieving sustainable development and that it could provide options for policymaking but should not be a rigid set of rules" (UNCSD Final Report 2012). The Conference was a failure from the point of view of progress in building up global governance (Viola and Franchini 2012).

The concepts of sustainable development and green economy imply deep socioeconomic restructuring, counterbalancing economic growth and environmental protection. They should give rise to an economic path that respects at least the eight identified and already quantified planetary boundaries, limits to human action before a systemic environmental disruption: (i) climate change; (ii) biodiversity loss; (iii) nitrogen cycle; (iv) phosphorus cycle; (v) stratospheric ozone depletion;

1 Pearce, Markandya and Barbier (1989): Blueprint for a Green Economy, New York, Earthscan. 
(vi) ocean acidification; (vii) global freshwater use; (viii) change in land use (Rockstrom et al. 2009; Viola, Franchini, and Ribeiro 2013, 60). Nevertheless, they are controversial and complex parameters, unable to guide effective policymaking; therefore, other parameters evolved from multilateral environmental negotiations, low carbon development among them. Low carbon development aims at a consistent reduction of GHG emissions per GDP unit (beyond the "normal" reduction derived from business as usual economic development), a clear direction to policy-making. Essentially, low carbon development path is embedded into the commitment of reducing carbon emissions, rendering economic growth and climate constancy structurally compatible (UNDESA 2012, 51).

Climate change is a complex topic: (i) it is intrinsically global, because it is centered around changes in concentration of atmospheric gases led by rising $\mathrm{CO} 2$, methane and nitrous oxide levels; (ii) it operates on a time scale that is beyond the human daily experience; (iii) it involves intra and intergenerational equity issues; (iv) it is not linear-it is not possible to identify direct cause and effect, since the causes of climate change are complex; (v) it challenges decision-making processes and institutions, which are not prepared to deal with non-linear issues (Steffen 2011, 22-26). Climate stability has been extremely relevant to human life since the Neolithic revolution-around eleven thousand year ago-, and could be classified as a key civilizational driver of the contemporary society, together with the expansion and deepening of globalization and the diffusion of democracy (Viola, Franchini and Ribeiro 2013).

Climate change mitigation requires stabilizing the concentration of GHG in the atmosphere, either by reducing emissions or capturing and storing carbon (CCS). ${ }^{2}$ In 1997, developed countries agreed on compulsory reduction emission targets and on mechanisms for their implementation. However, at the Kyoto Conference, they failed to set compulsory commitments for stabilizing emissions from fast-growing economies; therefore, the United States withdrew from the Protocol in 2001 (Viola 2002). The Kyoto Protocol was in force from 2005 to 2012. By the end of the period, three key developed countries (Japan, Russia and Canada) raised arguments similar to the American's and also withdrew. In 2013 the Protocol was a poor caricature of the Treaty signed in 1997: if in $199765 \%$ of global GHG emissions were constrained, in 2013 the commitment was reduced to only $12 \%$ of the total (mostly enforced by the European Union). At COP 18 (2012) countries established 2015 as the deadline for creating a legally binding agreement with commitments for all countries from 2020 onwards. At COP 19 (2013), a bitter debate on how to define the criteria for the new commitments took place between developed and developing countries. It is clear that such an agreement will not be achieved unless developing countries that account for relevant shares of current GHG emissions agree to undertake significant mandatory emissions

2 Articles 2 and 4 of UNFCCC, avaliable at <http://unfccc.int/files/essential_background/background_ publications_htmlpdf/application/pdf/conveng.pdf>, accessed on July 1, 2013. 
reduction targets for the period between 2020 and 2030 (Viola, Franchini and Ribeiro 2012).

Low carbon development requires implementation of measures that interfere in core issues of the contemporary lifestyle, such as energy sources and uses, institutions, governance, economic organization and values (Steffen 2011, 21; Jamieson 2011, 38-42); therefore it "will only be successfully achieved as a benefit contingent upon other goals which are politically attractive and relentlessly pragmatic" (Prins et al. 2009). Since CCS is still a limited option, ${ }^{3}$ it is imperative to reduce emissions. Energy supply and use accounts for more than $60 \%$ of world's GHG emissions, ${ }^{4}$ and it is likely that this share will increase even more once developing countries achieve higher levels of development. Hence the two main drivers for global decarbonization are increasing energy efficiency and disseminating low carbon energy sources (Viola, Franchini and Ribeiro 2013, 143), and success will only be possible if key countries are committed to these objectives.

In addition to the having the world's greatest population and the second largest economy, China is currently world's largest GHG emitter, energy producer and energy consumer. ${ }^{5}$ Without strong action from China, achieving global low carbon development is impossible; it is then vital to have China engaged in energy efficiency and low carbon energy sources.

\section{Chinese energy-climate profile}

China is the most populous country of the world, with 1,351 billion inhabitants in 2012-around 19\% of the world's total population-, and annual growth rate of $0.5 \%$. It is an upper middle income country, with GDP of US\$ 8,558 trillion and GDP per capita of US\$ 6,188 in 2012, both in an upward trend. Social inequality, however, is also rising: from 32.40 points in the Gini index in 1990, it marked 42.06 in 2009, and the numbers are growing ${ }^{6}$. In 2012, during a key Congress of the Communist Party of China, social inequality, as well as pollution and corruption, were considered the major challenges to be tackled in order to avoid a de-legitimation of the Party and the authoritarian regime.

In the energy sector, China is a country of superlatives: it has the largest total primary energy supply (2743 Mtoe in 2012, or $20.9 \%$ of the global production), and is the largest producer of coal (3574 MT in 2012, or 45.3\% of the global production, an increase of $750 \%$ from the 418 MT produced in 1973) and hydropower (699 TWh in 2012, or 19.6\% of the global amount). China is also

3 IEA (2013): Technology roadmap carbon capture and storage, available at <http://www.iea.org/publications/ freepublications/publication/TechnologyRoadmapCarbonCaptureandStorage.pdf>, access 15 Nov 2013.

4 http://www.grida.no/graphicslib/detail/world-greenhouse-gas-emissions-by-sector_6658

5 World Bank <http://data.worldbank.org/indicator>, access 18 Nov 2013.

6 World Bank <http://data.worldbank.org/indicator>, access 16 Nov 2013. 
the largest producer of electricity-4,716 TWh in $2011^{7}$ and surpassed United States as the major importer of oil in 2013. Its economy is energy intensive-it employed 2,727,727.6 kT of oil equivalent in 2010—, although per capita levels $(2,029 \mathrm{kT}$ of oil equivalent in the same year) are low when compared to OECD countries. ${ }^{8}$ Due to the distribution of its primary energy supply, Chinese energy matrix is essentially carbon intensive: in 2010, fossil fuels were the source of $84.1 \%$ of its energy—coal's share being $67.2 \%$ - and $80.6 \%$ of its electricity. ${ }^{9}$

China is highly vulnerable to climate change. ${ }^{10}$ Extreme weather events have become usual in the country: severe winters, torrential rains, typhoons, flooding and droughts are nowadays constant, and lead to electricity blackouts, water shortages, evacuation of millions people, deaths and many other losses. In the long run, the melting of Himalayan glaciers will alter regional hydrological regimes; arid regions will increase in size and number; sea level rise will lead to territorial losses in densely populated delta regions. Regardless, Chinese share in global GHG emissions have increased dramatically: it is currently the world largest emitter in absolute numbers $\left(8,286,892 \mathrm{kT} \mathrm{CO}_{2}\right.$ in 2010), and even if its per capita emissions are below the OECD average of 8.82 MT (6.20 MT in 2010), they are increasing yearly. ${ }^{11}$ The Chinese share in global carbon emissions was around $25 \%$ in 2012 and is predicted to increase around 1\% every year from 2013.

Chinese GHG emissions are related to the development path chosen by the country. If from 1978 to 2001 China's rapid growth of labor-intensive light manufacturing enabled the country to acquire energy efficient technology and integrate it to its capital stock, in 2001 the trend was reversed and the spread of energy intensive heavy industry led to increased energy intensity of its GDP (Rosen and Houser 2007, 9). The current main drivers of Chinese emissions are the energy sector and industrial processes. ${ }^{12}$ Within the energy sector, increase in emissions is related to the expansion of energy industries and transport services, both closely linked to Chinese urbanization - the share of urban population changed from $48 \%$ of the total in 2009 to $52 \%$ in $2012 .{ }^{13}$ Emissions from industrial processes, on the

7 IEA (2013): Key World Energy Statistics, available at <http://www.iea.org/publications/freepublications/ publication/KeyWorld2013_FINAL_WEB.pdf>, access 15 Nov 2013.

8 World Bank <http://data.worldbank.org/indicator>, access 16 Nov 2013.

9 Clean Energy Info Portal <http://www.reegle.info/countries/china-energy-profile/CN>, access 16 Nov 2013.

10 Information on the topic can be obtained from University of Columbia Socioeconomic Data and Applications Center (<http://sedac.ciesin.columbia.edu/mva/ccv/maps.html>), World Resources Institute (<http://insights.wri. org/news/2013/07/timeline-look-extreme-weather-and-climate-events-2013>) and Maplecroft (<https://www. maplecroft.com/about/news/climate_change_risk_list_highlights_vulnerable_nations_and_safe_havens_05. html>), access 16 Nov 2013.

11 World Bank <http://data.worldbank.org/indicator> and <http://iresearch.worldbank.org/PovcalNet/index. htm?2>, access 16 Nov 2013.

12 Emissions from the energy sector increased from $74.13 \%$ of total emissions in 1994 to $77.28 \%$ in 2005 , and the ones from industrial processes from $6.97 \%$ to $10.25 \%$ during the same period. UNFCCC, <https://unfccc. int/files/ghg_data/ghg_data_unfccc/ghg_profiles/application/pdf/chn_ghg_profile.pdf>.

13 World Bank, <http://data.worldbank.org/indicator/SP.URB.TOTL.IN.ZS>, access 16 Nov 2013. 
other hand, are related to the shift towards energy intensive manufacturing: e.g. emissions from halocarbons and SF6 - important elements for the production of steel, cement and other heavy products - accounted for only $3.05 \%$ of the sector's emissions in 1994 , but for $20.24 \%$ in $2005 .^{14}$

Between 1978 and 2000 energy demand grew at annual rate of $4 \%$, but after the 2001's shift it peaked 13\% (Rosen and Houser 2007, 4); the numbers have decreased in recent years, but they are still among the highest in the world. Even if China is successful in shifting its industry away from energy-intensive sectors, consumption and residential use (heating, cooling, lighting and transportation) current secondary drivers when compared to industrial energy demand-will become ever more important if the urbanization process keeps its pace (Rosen and Houser 2007, 8). Tackling Chinese GHG emissions, thus, means improving energy efficiency and massively employing low carbon energy sources in energy generation.

\section{China's energy-climate policy developments}

The pivotal piece of China's development planning is the Five Year Plan (FYP). Enacted every five years since 1953, it establishes the guidelines for the economic development of the period, according to the priorities set by the Communist Party of China. The Soviet Union centralized planning was the inspiration for the FYP. Between 1953 and 1977, however, the China lacked technical capabilities for FYP implementation, and their outcomes were mixed: periods of fast growth were followed by massive crises, such as the crisis during the attempt of economic decentralization in 1956-58 and the political upheaval during the Cultural Revolution of 1966-68. In 1978, FYP became more technical: laws and regulations are developed within its framework, in order to translate into policy the broad objectives of the FYP. After the $10^{\text {th }} \mathrm{FYP}$, the plans were nominated Five Year Guidelines (FYG).

Energy is a cornerstone of economic development. After the explosion of growth rates that followed the 1978 reforms, energy security became a constant concern in Chinese planning. Due to very small oil reserves known at the time and the 1973 international oil crisis, coal mining became strategic. Securing its steady exploitation and keeping energy prices low were the main objectives of planning for decades, and energy security still plays a central role in Chinese policymaking-it is important to remember that growth and political legitimacy of the authoritarian regime have always been intricately linked (Hallding, Hand and Olsson 2009, 121). Following the economic expansion, access to energy gained policy momentum. In order to expand energy services to include hundreds of millions of Chinese, further investments in infrastructure and coal production were determined.

14 UNFCCC, <https://unfccc.int/files/ghg_data/ghg_data_unfccc/ghg_profiles/application/pdf/chn_ghg_ profile.pdf>, access 15 Nov 2013. 
The impressive Chinese growth rates during the 1980s have improved socioeconomic standards, but at a considerable cost to public health and the environment. Nevertheless, concerns over the carbon and energy intensive development path were usually driven by economic performance-consuming less energy would reduce costs and make Chinese products more competitive (Rosen and Houser 2007, 7). ${ }^{15}$ It was not until the $21^{\text {st }}$ century that the pursuit of economic growth by itself started to be seriously questioned.

The $11^{\text {th }}$ FYG (2006-2010) initiated the change. The plan aimed at achieving a so-called "Harmonious Socialist Society" through a development path that "takes into consideration the welfare of disadvantaged peoples and regions as well as environmental concerns" (Fan 2006, 709). This "Scientific Development," as well as relatively fast - a definition applied to development in all FYP —, should be steady, environmentally sustainable and socially inclusive (Fan 2006, 709). Climate change, once a marginal issue in policymaking, became very important-evidence given by the number of provisions of the $11^{\text {th }}$ FYG direct or indirectly related to climate change mitigation. A combination of factors contributed to this shift: concerns over energy security; ${ }^{16}$ increased awareness of the Chinese vulnerability to climate change; fear of undertaking United States' role as world's "climate villain"; increasing demands from grassroots movements' for environmental quality; and the will to become a technological and economic leader in a low carbon world (Viola, Franchini and Ribeiro 2012; Boyd 2012).

In the energy-climate domain, the $11^{\text {th }}$ FYG aimed at decreasing energy intensity of GDP by $20 \%$ and major pollutant-sulfur dioxide and chemical oxygen demand, which contribute to the increase of GHG concentrationemissions by $10 \%$ (from 2005 levels). It also established energy conservation and emission reduction objectives for each region, sector and individual business, and enhancing non fossil fuel sources on the primary energy consumption to $10 \%$ by 2010 and $15 \%$ by 2020 - with specific targets for expanding the installed capacity of each renewable energy source: $300 \mathrm{GW}$ for hydro, $30 \mathrm{GW}$ for wind, $1.8 \mathrm{GW}$ for solar photovoltaic and $30 \mathrm{GW}$ for biomass-based sources.

In order to achieve the $11^{\text {th }}$ FYG objectives, several policy measures were undertaken. Regarding energy efficiency and energy conservation: the Energy Conservation Law was revised; benchmarking in key sectors, such as construction and transportation, was established, as well as the Top-1000 Enterprises Energy Conservation Programme; ${ }^{17}$ energy pricing was coupled with energy efficiencyhigher energy costs for businesses that did not meet energy efficiency standards,

15 During the 1990s, there were some policy initiatives to integrate health and environmental concerns into, very limited in scope, though.

16 Due to increased energy consumption and recent shortages, renewable energy production is seen as necessary to increase energy security in China.

17 The program encourages key energy intensive businesses to engage in energy auditing, to report their usage, and to put forward energy conservation plans. 
and financial rewards for the ones that saved energy—; public transport, alternative fuels, combined heat-and-power, surplus heat utilization, green lighting, high performance appliances and energy saving buildings were envisaged. Regarding energy production from low carbon sources: the Medium and Long-term Development Plan for Renewable Energy was approved; higher taxes on oil, coal and natural gas were authorized; operators of power grids were required to buy energy from renewable energy producers; feed-in tariffs, discounted lending and the creation of a national fund to foster renewable energy development were established; guidelines for renewable energy industries—setting technical standards for renewable energy electrical power, technology, and products-were published; rules designed to encourage the construction of renewable power generation facilities, efficient buildings, and rural electrification were designed. The national legislative effort was supplemented by financial support for Research and Development $(\mathrm{R} \& \mathrm{D})$ on key renewable energy technologies, and by provincial and local regulation on the same issues (Held, Nag and Roger 2011, 29-31). In addition, the Chinese central government and several local governments from the coastal region engaged in diplomatic talks and offered economic incentives to attract investments from Taiwanese enterprises that had a leading role in developing low carbon energy technologies.

In June 2007, China issued its National Climate Change Program, the first comprehensive policy framework for tackling climate change, and in December its first White Paper on Energy Conditions and Policies, shaping action towards energy efficiency, energy conservation and renewable energy. But 2008 was the turning point of Chinese energy and climate policy. The Chinese government reacted in a very progressive way to the global financial crisis, and launched a stimulus economic package in November 2008 (US\$ 850 billion), allocating 35\% of the resources to low carbon development. It was the second largest low carbon stimulus package in the world, after South Korea's (65\%); developed countries allocated around 20\% of resources to the same purpose (United States, France, Germany and United Kingdom); Brazil, India and Russia, allocated none (Viola, Franchini and Ribeiro 2013). In 2009, before COP 15, sectors of the Chinese government were ready for deeper commitment on energy-climate, and expectations of convergence between United States and China were high—but were, unfortunately, frustrated during the negotiations (Viola, Franchini, and Ribeiro 2013).

In the current $12^{\text {th }}$ FYG (2011-2015), China advances the concepts of Scientific Development and Harmonious Society. Predicting an annual GDP growth of $7 \%$ for the period, China aims at reducing social inequality and protecting the environment. Energy efficiency and energy conservation remain at the core of the central planning. The country plans to reduce its energy intensity by $16 \%$ and its carbon intensity by $17 \%$ (from 2005 levels); non fossil fuel energy sources should amount to $11.4 \%$ of primary energy consumption until 2015 , and $15 \%$ until 2020. Significant investments are predicted in controlling pollution, 
especially emissions from sulfur dioxide and chemical oxygen demand-which should decrease in $8 \%$ in the period — and from ammonia nitrogen and nitrogen oxides - with targeted reduction of $10 \%$. China is planning to expand both low carbon energy sources installed capacity-in $105 \mathrm{GW}, 40 \mathrm{GW}$ from nuclear, $70 \mathrm{GW}$ from wind and $5 \mathrm{GW}$ from solar ${ }^{18}$ - and power grid (smart grid national standards are being developed). Further investments are planned for public transportation. The plan also benefits seven "strategic emerging industries" with tax exemptions and beneficial procurement policies, among which new energy, energy conservation and environmental protection and clean energy vehicles.

China is also embarking in carbon trading. The decision was motivated by the evidence that command and control policy measures — such as mandatory targets for energy efficiency and renewable energy production-lay the foundation of the low carbon development path, yet, due to the globalized world economy, are not enough to put China on this track. Market-based instruments "are now widely recognized as indispensable policy tools that would help China meet its energy and carbon intensity targets - both domestic and international-in a more controlled, monitored, and/or predictable way" (Han et al. 2012, 5). Pilot carbon emissions trading schemes have been set in seven cities and provinces-Beijing, Shanghai, Tianjing, Chongqin, Shenzhen (the five cities), Guangdong and Hubei (the two provinces). During this pilot phase, local governments are to decide upon the sectors to integrate the schemes and the means of capping, and different implementation paths are being tested. The objective of the piloting is to develop best practices in order to expand the programs at a regional level (by 2014) and at a national level (by 2016). In addition, proposals for sector-based schemes, targeting energy-intensive industrial sectors, such as electricity and building, are under consideration (Han et al. 2012, 21-33).

Achievements of the $11^{\text {th }}$ FYG were substantial, but very heterogeneous and not enough to change the high carbon emissions profile of the Chinese energy matrix. In energy efficiency, the greatest failure was the lack of compliance of coal fuelled thermal power plants with efficiency standards-failing, consequently, to reduce local pollution levels; however, even if the $20 \%$ target was not reached, there were important results: ${ }^{19}$ China has closed most obsolete power generation, iron and steel plants; it has employed energy-efficient technologies and materials in heating. China has also improved automotive fuels and made massive investments in transit systems - even if the expansion of automotive production that occurred in the same period and led the country to rate $1^{\text {st }}$ in world's automobile production, is leading to the large and long traffic congestions in major metropolitan areas

18 Hydropower plants amounting to $120 \mathrm{GW}$ are also planned.

19 In a period when GDP increased 10\% annually, a 14.4\% (Economy 2010, 4) or 18\% (Held, Nag and Roger 2011,32-33) energy intensity reduction is substantial. Economy stresses that the target was missed because the 2008-2010 fiscal stimulus package encouraged enormous investment in heavy industry and infrastructure, both energy intensive sectors. 
and roads connecting them. There were significant achievements in deploying renewable energy: China is currently the world's largest producer ${ }^{20}$ and consumer of renewable energy, but in both cases in absolute numbers, not in per capita or per unit of GDP base. It became the largest market for wind turbines, and it is the world's third manufacturer of solar photovoltaic panels, but the share of low carbon energy of its matrix is still $4 \% .{ }^{21}$ It is early to judge the results of the $12^{\text {th }}$ FYG, but partial evidence point to the resistance of sub-national governments (at the Centre and West of the country) to its guidelines: new records of pollution in major cities are a clear indication of constraints in central planning implementation. In a period of global economic deceleration, it is unlikely that the Chinese pace towards low carbon development will be boosted.

\section{China in energy and climate global governance}

Three energy governance arenas have emerged in contemporary International Relations: energy security, access to energy and sustainable energy production and use. Energy has always been a national security concern, but energy security becomes a multilateral issue after the oil shocks of the 1970s. The main actors of this arena are states and their alliances, and their main objective is some stability and predictability of oil prices, although economic development, trade, nuclear proliferation, corruption and good governance practices may also be included in the discussions (Cherp, Jewell, and Goldthau 2011, 81). Access to energy emerges during the 1980s and is embedded in the international development agenda. Access to modern energy sources to all humankind is the main objective of the arena. The discussions encompass infrastructure, technology, modern fuels and household appliances, poverty alleviation and sustainability, and the main actors are development organizations, international and regional development banks and non-governmental organizations (NGOs) (Cherp, Jewell and Goldthau 2011, 81-82). The third arena is mostly complex. Although some of its roots can be found in both previous arenas and it remains interrelated to them, it evolved into an independent negotiating path during the 1990s, when environmental externalities from the production and use of energy became evident. Discussions involve states, international organizations, NGOs, scientists, the development community, businesses, transnational institutions and civil society (Cherp, Jewell and Goldthau 2011, 82-83). Since GHG emissions are the main cause of climate change and energy systems account for most of their amount, the third energy arena and the climate regime are intrinsically connected, and their common objective is decarbonizing world energy systems, achieving a low carbon

20 The PEW Charitable Trusts (2012): Who is winning the energy race, available at <http://www.pewenvironment. org/news-room/reports/whos-winning-the-clean-energy-race-2012-edition-85899468949>, access 12 Jul 2013.

21 Clean Energy Info Portal <http://www.reegle.info/countries/china-energy-profile/CN>, and World Bank <http://data.worldbank.org/indicator/EG.USE.COMM.CL.ZS/countries>, access 28 Jul 2013. 
development path. Due to the unprecedented nature of this challenge, energy and climate change have become defining elements of foreign policy, and "new energy foreign policy transforms the character of existing geopolitical rivalries" (Müller-Kraenner 2008, 1).

The climate regime involves the UN multilateral arena, major powers energyGHG emissions trajectories and transnational governance. While countries are the privileged actors of the UNFCCC, the scientific community, multinational corporations and global NGOs have an important role in setting the agenda.

China's position in multilateral climate negotiations has been fairly consistent over the years, but some important changes took place recently. China sees itself as part of G-77, countries that lagged behind in development and have the legitimate right to pursue it through their own efforts and aid from the international community. The group defends common but differentiated responsibilities and respective capabilities in tackling climate change: historically responsible developed countries should take the lead in reducing GHG emissions, developing technologies - and transferring them to developing countries - and establishing funding mechanisms to deal with the problem. This is the Chinese baseline position; in fact, China has had one of the most conservative hard line interpretations of the principle of common but differentiated responsibilities and respective capabilities: almost all the responsibilities are differentiated, just a small proportion is common. Benjamin Gilman characterized China's climate discourse as "a policy of 'three noes': no obligations on China, no voluntary commitments by China and no future negotiations to bind China" (apud Held, Nag and Roger 2011, 39).

Nevertheless, China changed its position on flexibility mechanisms established to implement targeted emissions reductions. During the UNFCCC negotiations, China had argued against the establishment of the Joint Implementation, considered "an unfair practice which would allow developed countries to shirk their responsibilities, and would involve a violation of sovereignty due to the invasive monitoring and verification measures that would be needed" (Held, Nag and Roger 2011, 35). When the Kyoto Protocol was being discussed, however, China favored the Clean Development Mechanism (CDM), still suspicious that the mechanism could be controlled and serve the interests of developed countries only, though. China has the largest number of CDM projects and Certified Emission Reduction (CER) credits in the world. ${ }^{22}$

Regarding technology transfer, China’s discourse evolved from demanding direct and unpaid transfers from developed countries to proposing "reciprocal technology cooperation" between industrialized and developing countries, a win-win solution (Held, Nag and Roger 2011, 38). China still objects binding commitments to developing countries-based on their low GHG emissions per

22 Until 2012, Asia hosted $81.4 \%$ of all CDM projects and received $80.1 \%$ of all CERs; China hosted $55.5 \%$ of Asia's projects, and received $72 \%$ of Asia's CERs. UNEP Risoe CDM/JI Pipeline Analysis and Database (November 1st 2013), available at <http://www.cdmpipeline.org>, access 22 Nov 2013. 
capita-, but some minor changes in two of the "three noes" have taken place: at COP 13 (2007), China voted for the establishment of the Ad Hoc Working Group on Long-Term Cooperative Action (AWG-LCA); ${ }^{23}$ and at COP 15 (2009), China has voluntarily pledged to reduce $40-45 \%$ of its GDP carbon intensity by 2020 (compared to a business as usual scenario) — an easy target considering the Chinese fast rates of economic development and the gains in energy and input efficiency that follow them.

Considering China's official position at recent COPs, there is an upward trend between 2009 and 2011, and a downward trend after that in. In 2009, due to the international enthusiasm about climate change and following the Lula-Sarkozy pre-COP 15 meeting-in which the United States and China were pressed for deeper commitment towards climate change- the two greatest GHG emitters were expected to undertake binding GHG emission reduction targets. During COP 15, however, the United States failed to adopt a vanguard position, and China announced a voluntary pledge — an advance compared to its position during the policy of three nos, but a disappointing outcome compared to the one that was expected. In 2011, China stated that it would accept legally binding commitments for the post-2020 period. Notwithstanding, China's progressive position was weakened after Durban, and old arguments regained their strength. At COP 19 (2013), China called upon the developed countries to ratify the second commitment period of the Kyoto Protocol and to set higher emission-cutting target in line with the agreement reached at the Doha Conference; it clashed with the European Union by rejecting commitments to reduce its emissions starting on 2020; it continued to dilute its climate responsibilities in the magma of developing countries, and strongly supported the Brazilian regressive position of reintroducing the concept of historical responsibilities in negotiations-a recipe for failure of international cooperation, since blaming the present generation for the behavior of previous generations leads to perpetual conflict in international relations. ${ }^{24}$

Being the most populous country in the world and the largest GHG emitter, China's importance in energy and climate governance is not challenged. It is a climate superpower, and its actions have great impact on the global carbon cycle and the regime. Sustaining its membership in the G-77 is no longer easy: "for many developing countries, climate change has revealed China as less and less 'one of us' and more and more 'one of them"' (Economy 2010,2). China and other emerging countries are currently being pressed to join the developed countries in accepting mandatory GHG emissions reduction targets by 2020; the BASIC (Brazil, South Africa, India and China) coalition has emerged in this context, and now occupy an inconsistent and foggy position in the climate regime, sometimes

23 The AWG-LCA is mandated to consider mitigation actions by developing countries.

24 Brazil had abandoned the doctrine of historical responsibilities in 2009, during its major progressive shift in climate policy. The resurgence of the doctrine in late 2013 was a major surprise for the Brazilian scientific community and will likely not last. 
pretending to be in-between developed countries and the G-77, but most of the times stressing that they remain firmly anchored within the G-77 (Hallding et al. 2011; Viola, Franchini, and Ribeiro 2013, Hochstetler and Viola 2012). ${ }^{25}$

China has taken part in energy regional cooperation agreements, such as the Shanghai Cooperation Organization, ${ }^{26}$ and has enhanced bilateral partnerships to include energy issues: e.g. the exchange of wind energy and biofuels technologies with Brazil; the state visits to Central Asia in September 2013 in order to strengthen cooperation on energy issues (an agreement on a natural gas pipeline project from Turkmenistan to China was signed). Embracing its emerging role, and looking for further energy sources, the country has developed a new Africa policy, allocating development aid grants in countries where Chinese companies invest in resource extraction, in some cases replacing previous colonial powers and traditional aid donors-such as developed countries and the IMF (Müller-Kraenner 2008, 9-11). It has also enhanced its participation in transnational governance. Some of the current initiatives with Chinese sub-state and non-state actors participation are: (i) C40 Cities: Climate Leadership Group; ${ }^{27}$ (ii) The Gold Standard Foundation carbon credit certification scheme, ${ }^{28}$ and (iii) the Innovation Center for Energy and Transportation. ${ }^{29}$

While changing its positions and enhancing cooperation, Chinese diplomacy is mostly trying to secure access to energy sources or to financial resources for its economic development process. There is a growing sense of China's vulnerability to climate change and the desire to bolster its international image as a responsible power, but these are arguments of the Chinese elite, the same group that pushes toward low carbon technology investments. Due to the conflicts between the traditional irresponsible position and the new reformist groups, China can now be classified as a moderate conservative climate superpower-still reluctant to undertake GHG emissions mandatory targets and avoiding to fully compromise

25 It is not easy to establish a profile of the BASIC coalition. The countries are mostly heterogeneous, both in energy and climate. Despite its recognition in multilateral negotiations and its quarterly Ministerial Meetings, it is right to say that the coalition still lacks a profile and common positions. For further insights, see Basso (2013): 'A ascensão do BASIC e seu conservadorismo no regime internacional das mudanças climáticas' in Direito internacional de nosso tempo - desafios, fundamentos e integração, v. 1, Belo Horizonte, Arraes, p. 197-211.

26 Having China, Kazakhstan, Kyrgyzstan, Russia, Tajikistan and Uzbekistan as members, and other Middle East and Asian countries as observer states and dialogue partners, the group has large scale projects related to energy (<http://www.sectsco.org $>$ ).

27 A network of the world's largest cities committed to reduce carbon emissions and increase energy efficiency; Beijing, Shanghai and Hong Kong are members (<http://www.c40cities.org $>$ ).

28 The scheme certifies carbon credits of projects that reduce GHG emissions while contributing to sustainable development (<http://www.cdmgoldstandard.org >).

29 A partnership between Beijing and California, the center was created to strengthen international cooperation and provide innovative solutions to solve the energy, environment, and climate crises to decision makers at all levels. The think tank has created, in 2009, the Energy and Carbon Registry, the first carbon and energy efficiency registry in the country, and, in 2013, the China Climate Registry, the first Chinese non-profit greenhouse gas accounting and reporting platform ( $\leq$ http://www.icet.org.cn/english/index2.asp $>$ ). 
with the global climate governance, but moving towards this direction at a gradual pace (Viola, Franchini and Ribeiro 2013).

\section{Challenges for China's low carbon development}

In the last decade China has moved towards low carbon development, but in a very contradictory way; and it faces important challenges to advance its implementation.

One of the challenges is dealing with the complicated bureaucratic structure and overlapping competencies in energy policymaking. Chinese energy authority has always been splintered among multiple government institutions and industries, frustrating the formulation, implementation and enforcement of policies (Downs 2008, 42). China has no Ministry of Energy; the institutional competition among its several major energy industry authorities has undermined the ability to centralize energy regulation. In 2003, the National Development and Reform Commission (NDRC) ${ }^{30}$ established the Energy Bureau, a compromise solution between the NDRC — in favor of centralization — and the powerful energy State Owned Enterprises-in favor of decentralization. The Energy Bureau not only ranked lower than the Ministries and the energy SOEs in the Chinese bureaucratic hierarchy; it also lacked manpower, financial resources, autonomy and authority to fulfill its mission (Held, Nag and Roger 2011, 26). In 2008, China created the National Energy Commission (NEC), a high level discussion and coordinating body, formulating energy strategy and deliberating on key issues such as energy security and energy development (Burke, Jansson and Jiang 2009, 10; Downs 2008, 43), and the National Energy Administration (NEA), replacing the Energy Bureau and responsible for the implementation of NEC's strategies (Burke, Jansson and Jiang 2009, 9-10; Downs 2008, 43). Nevertheless, issues such as lack of manpower, autonomy, authority and tools to implement policies remain (Downs 2008, 43)-e.g. energy pricing is still an attribution of the NDRC. ${ }^{31}$

Another challenge is the conflict of priorities for central and local governments. Against rationalist neo-realist assumptions, China is not a monolithic unitary actor with high levels of unity, and the central government lacks the ability to impose its positions across the entire state apparatus (Burke, Jansson and Jiang 2009, 2;

\footnotetext{
30 The NDRC is the most powerful executive authority of the Chinese administration; while the Communist Party of China and the State Council settle the guidelines of the Chinese development, the NDRC is responsible for enacting the policies to implement them.

31 China’s climate bureaucracy faced a similar issue: climate change has entered the Chinese bureaucracy through the State Meteorology Administration, moved into the NDRC attributions, later to the State Council and, from 2007, is dealt with by the National Leading Committee on Climate Change (NLCCC), headed by the Premier and coordinating 27 different government agencies. After the creation of the NLCCC, climate change became a central concern in Chinese policymaking. Subnational governments have their own climate change structures, responsible for the implementation of the Chinese central government decisions (Held, Nag and Roger 2011, 23-24).
} 
Hallding, Hand and Olsson 2009, 130-131). Conflicts among leaders and clients of national, provincial and municipal levels are common: e.g. one of the biggest challenges to shift China's economy away from energy intensive industrial production and towards a high tech industrial production and a services economy is the competition among provinces, counties and cities to grow GDP, the capital stock, tax revenues and corporate profits (Rosen and Houser 2007, 9). Local interests include not only local government ones, but also industrial enterprises, sometimes more powerful than them; and given that implementation of policy is always a local issue (Rosen and Houser 2007, 9), idiosyncratic policy implementation can invalidate the purposes of the central planning.

Imbalances between command and control and market mechanisms also affect the energy policymaking (Hallding, Hand and Olsson 2009, 130). Effective and independent legal institutions and real opportunity for bottom-up policy initiatives are both absent in China; hence, market-based instruments are rare in Chinese policymaking, and their lack may undermine the full implementation of planning guidelines (Hallding, Hand, and Olsson 2009, 130-131). In this context, the decision to pilot carbon emissions trading schemes in order to offer financial incentives for reducing carbon emissions is a cornerstone in altering the imbalance. Lack of institutional capacity, adequate data collection and proper monitoring, reporting and verification mechanisms must also be tackled (Rosen and Houser 2007, 18; Hallding, Hand and Olsson 2009, 130-131).

Finally, the Chinese domestic energy and climate policy efforts should be reflected in the international arena. China is the largest GHG emitter and energy consumer in the world; the voluntary pledge to reduce its GHG emissions in $40-45 \%$ by 2020 is insufficient to meet the global quest for Chinese compromise with climate change or the necessary Chinese co-leadership in the global transition to a low carbon economy. Since 2006, China has moved towards low carbon development, but it still misses important policy implementation in order to have its society consistently on this path.

\section{Conclusion}

In the last decade, China has undergone an important shift in its energyclimate policymaking. The $11^{\text {th }}$ FYG (2006-2010) and the US\$ 300 billion allocated to low carbon development in 2008 were turning points in Chinese central planning: for the first time, economic growth was coupled with welfare needs of disadvantaged peoples and environmental concerns; laws and regulations aimed at reducing China's energy intensity, major pollutant emissions and GHG emissions were enacted; targets for expanding the production of renewable energy were established. The $12^{\text {th }}$ FYG (2011-2015) reinforces these objectives, and is piloting carbon emissions trading schemes. Considering its starting point-a 
carbon intensive energy matrix, and extremely irresponsible and nationalistic climate policies-China has improved its energy-climate profile towards low carbon development; yet, by trying to reconcile long-term investments and vested interests in the old highly intensive carbon industries and the desired leadership of the envisaged low carbon global economy, China has been contradictory and did not embrace the leading role that is expected from a climate superpower.

Conflicting societal objectives and values foster the contradiction. On the one hand, grassroots movements protesting against local pollution levels caused by coal power plants and the effects of extreme weather events, elite groups targeting market opportunities of a low carbon economy, and the government's objectives of increasing China's energy security and enhancing its soft power by bolstering the image of a responsible power are the main drivers in favor of a low carbon path. On the other hand, overlapping competencies of the numerous Chinese authorities dealing with energy policy, conflicting priorities between central and local governments and vested interests of high carbon industries and their clients are the main obstacles for change. In order to achieve a deeper compromise with low carbon development, China must tackle its complicated bureaucratic structure, the imbalances between command and control and market based mechanisms, and the lack of real opportunities for bottom-up policymaking.

The Chinese authoritarian regime is a major constraint for a consistent engagement in global energy and climate governance. By definition, an authoritarian regime concentrates the sovereign power at the national level; it resists yielding power to supranational authorities and does not hesitate to curtail individual rights or civil liberties when its ascendancy is challenged. After the China's Third Plenum - a meeting of the leaders of the Communist Party of China that took place in November 2013-, the central government announced reforms in the economic model: deepening market liberalization, moving from an export led development to a domestic consumer growth development, withdrawing central government subsidies to inefficient industries, increasing bank transparency, increasing energy efficiency and decreasing pollution. These reforms are in tandem with a slow transition to a low carbon economy but postpone the rapid transition that, according to scientists, is required to avoid dangerous and irreversible climate change.

From the point of view of political liberalization, the results of the Plenum were disappointing; it seems that the Communist Party fears even minimal political democratization, let alone a multiparty democracy. It is uncertain how long a growing and empowered Chinese middle class will keep up with political authoritarianism. Perhaps the demand for enhanced environmental quality could be the major driver for commitment with global energy and climate governance and political liberalization. Embracing low carbon development will definitely need both. 


\section{Bibliographic references}

BASSO, Larissa (2013): 'A ascensão do BASIC e seu conservadorismo no regime internacional das mudanças climáticas', in: CAPUCIO, Camila et al. (orgs.); Direito internacional de nosso tempo - desafios, fundamentos e integração, v. 1, Belo Horizonte, Arraes, p. 197-211.

BOYD, Olivia T. (2012): 'China's energy reform and climate policy: the ideas motivating change', CCEP Working 1205, Centre for Climate Economics \& Policy, Crawford School of Economics and Government, The Australian National University, Canberra.

BURKE, Christopher; JANSSON, Johanna; JIANG, Wenran (2009): Formulation of Energy Policy in China: Key Actors and Recent Developments, Centre for Chinese Studies, University of Stellenbosch, available at <http://www.revenuewatch.org/sites/default/files/Formulation\%20 of\%20Energy\%20Policy\%20in\%20China.pdf>, accessed 15 Nov 2013.

CHERP, Aleh; JEWELL, Jessica; GOLDTHAU, Andreas (2011): 'Governing global energy: systems, transitions, complexity, in: Global Policy, v. 2, issue 1, p. 75-88.

DOWNS, Erica S. (2008): Chinas "New" Energy Administration, [online] <chinabusinessreview. com>, accessed 18 Nov 2013.

ECONOMY, Elizabeth C. (2010): China's Green Energy and Environmental Policies, testimony before the US-China Economic \& Security Review Commission of the United States House of Representatives, [online] <http://www.cfr.org/environmental-policy/chinas-green-energyenvironmental-policies/p21855>, accessed 18 Nov 2013.

FAN, C. Cindy (2006): 'China’s Eleventh Five-Year Plan (2006-2010): From "Getting Rich First" to "Common Prosperity", in: Eurasian Geography and Economics, v. 47, n. 6, p. 708-723.

HALLDING, Karl, et al. (2011): Together Alone: BASIC countries and the climate change conundrum, Nordic Council of Ministers, Copenhagen, available at <http://www.seiinternational.org/mediamanager/documents/Publications/Climate/sei-basic-preview-jun2011. pdf>, accessed 18 Jul 2013.

HALLDING, Karl; HAN, Guoyi; OLSSON, Marie (2009): 'China's climate and energy security dilemma: shaping a new path of economic growth', Journal of Current Chinese Affairs, v. 38, n. 3, p. 119-134.

HAN, Guoyi et al. (2012): 'China's Carbon Emission Trading, an Overview of Current Development', FORES Study 2012: 1, available at <http://www.sei-international.org/ mediamanager/documents/Publications/china-cluster/SEI-FORES-2012-China-CarbonEmissions.pdf>, accessed 17 Nov 2013.

HELD, David; HAG, Eva-Maria; ROGER, Charles (2011): The governance of climate change in China, Preliminary Report LSE-ADF Climate Governance Program, available at <http:// www.lse.ac.uk/globalGovernance/publications/workingPapers/climateChangeInChina.pdf>, accessed 17 Nov 2013.

HOCHSTETLER, Katheryn; VIOLA, Eduardo (2012): "Brazil and the Politics of Climate Change: Beyond the Global Commons”, in: Environmental Politics, v. 21 n. 5, p. 753-771.

INTERNATIONAL ENERGY AGENCY (2013): Key World Energy Statistics, available at <http:/www.iea.org/publications/freepublications/publication/KeyWorld2013_FINAL_WEB. pdf>, accessed November 1, 2013. 
JAMIESON, Dale (2011): 'The nature of the problem', in: DRYZEK, John S.; NORGAARD, Richard B.; SCHLOSBERG, David (eds.); The Oxford Handbook of Climate Change and Society, Oxford, OUP, p. 38-54.

MÜLLER-KRAENNER, Sascha (2008): 'China's and India’s Emerging Energy Foreign Policy', German Development Institute Discussion Paper 15/2008, available at <http://worldfellows.yale. edu/sites/default/files/files/DIEChinasandIndiasEmergingEnergyForeignPolicy.pdf>, accessed 17 Nov 2013.

NATIONAL DEVELOPMENT AND REFORM COMMISSION (2013): China's Policies and Actions for Addressing Climate Change, available at <http://www.ndrc.gov.cn/gzdt/ W020131107539684396470.pdf> accessed 15 Nov 2013.

PRINS, Gwyn, et al. (2010): The Hartwell Paper - a new direction for climate policy after the crash of 2009, London School of Economics and University of Oxford, available at <http:// eprints.lse.ac.uk/27939/1/HartwellPaper_English_version.pdf>, accessed August 2, 2013.

ROCKSTROM, Johan, et al. (2009): 'A safe operating space for humanity', in: Nature, v. 461, 24 set 2009, available at <http://www.nature.com/nature/journal/v461/n7263/full/461472a. html>, accessed July 1, 2013.

ROSEN, Daniel H.; HOUSER, Trevor (2007): 'China energy: a guide for the perplexed', Peterson Institute for International Economics working paper, available at <http://www.iie.com/ publications/papers/rosen0507.pdf>, accessed 18 Nov 2013.

STEFFEN, Will (2011): 'A truly complex and diabolical policy problem', in: DRYZEK, John S.; NORGAARD, Richard B.; SCHLOSBERG, David (eds.); The Oxford Handbook of Climate Change and Society, Oxford, OUP, p. 21-37.

THE PEW CHARITABLE TRUSTS (2012): Who is winning the energy race, available at <http://www.pewenvironment.org/news-room/reports/whos-winning-the-clean-energy-race2012-edition-85899468949>, accessed 12 Jul 2013.

UNDESA (2012): A guidebook to the green economy, available at <http://www.uncsd2012.org/ content/documents/528Green\%20Economy\%20Guidebook_100912_FINAL.pdf>, accessed 28 Jun 2013.

UNEP (2011): Towards a Green Economy: Pathways to Sustainable Development and Poverty Eradication, available at <http://www.unep.org/greeneconomy/Portals/88/documents/ger/ ger_final_dec_2011/Green\%20EconomyReport_Final_Dec2011.pdf>, accessed July 1, 2013.

UNITED NATIONS CONFERENCE ON SUSTAINABLE DEVELOMENT (2012): The future we want; United Nations General Assembly Resolution A/RES/66/288, available at <http://daccess-dds-ny.un.org/doc/UNDOC/GEN/N11/476/10/PDF/N1147610. pdf?OpenElement>, accessed July 1, 2013.

VIOLA, Eduardo (2002): 'O Regime Internacional da Mudança Climática e o Brasil'; in: Revista Brasileira de Ciências Sociais, v. 17, n. 50, p. 25-46.

VIOLA, Eduardo; FRANCHINI, Matías (2012): ‘Os limiares planetários, a Rio+20 e o papel do Brasil', in Cadernos EBAPE, v. 10, n. 3, p. 470-491.

VIOLA, Eduardo; FRANCHINI, Matías; RIBEIRO, Thais Lemos (2012): 'Climate Governance in an international system under conservative hegemony: the role of major powers'; in: Revista Brasileira de Política Internacional, v. 55, special ed., p. 9-29. 
VIOLA, Eduardo; FRANCHINI, Matías; RIBEIRO, Thais Lemos (2013): Sistema internacional de hegemonia conservadora - governança global e democracia na era da crise climática; São Paulo, Annablume.

WORLD COMMISSION ON ENVIRONMENT AND DEVELOPMENT (1987): Our Common Future, Document A/42/427 of the Secretary-General of the United Nations, available at <http://www.un-documents.net/wced-ocf.htm>, accessed July 1, 2013.

Submitted November 30, 2013

Accepted February 5, 2014

\begin{abstract}
If the world is not to jeopardize the chances for human life on Earth, climate change must be mitigated; therefore, achieving low carbon development is crucial. China is the world's greatest GHG emitter, energy producer and energy consumer; investigating its energy-climate policy developments and international positions are of utmost importance to understand and tackle current stumbling blocks of the global energy and climate governance.
\end{abstract}

Keywords: climate change; global energy and climate governance; low-carbon development.

\title{
Resumo
}

Se o mundo não quiser colocar em risco a continuidade da vida humana na Terra, as mudanças climáticas precisam ser mitigadas, e alcançar o desenvolvimento de baixo carbono é essencial. A China é o maior emissor de gases de efeito estufa e o maior produtor e consumidor de energia; investigar os desdobramentos de suas políticas em energia e clima e suas posições internacionais nos temas é fundamental para compreender e enfrentar os obstáculos da governança energética e climática global.

Palavras-chave: mudanças climáticas; governança energética e climática global; desenvolvimento de baixo carbono. 